\title{
Egill and Qlrún in Early High German
}

Bernard Mees (University of Tasmania)

Wolfgang Beck (2017) has offered an extended criticism of the interpretation of the apparently metrical Pforzen inscription proffered most fulsomely by authors such as Edith Marold $(1996,2004)$ and Robert Nedoma (1999, 2004a) concluding: "all that can be said with any certainty is that the Pforzen inscription contains two pre-Old High German personal names in a context that cannot be further elucidated." The key to interpreting the verb-final inscription on the late-sixth-century Pforzen buckle, however, is generally recognised to be how to explain the appearance of the alliterating names Aigil and Ailrün paired by the conjunction andi 'and' in the inscription's first line. Associated by scholars such as Marold and Nedoma with the Old Norse heroic pair of Egill and Qlrún, both of the Pforzen names seem to evidence a palatal development in their first syllables - the underlying Germanic roots for the relevant themes of the Old Norse pairing appear to be *agil- and *al-, not *aigil- and *ail-. Claimed by Martin Findell $(2012,193)$ to be "unmotivated" (cf. Nedoma 2004b, 163-65), palatal developments of this kind are attested in the earliest Old High German glosses and are consistent with the palatalisation or Mouillierung theory of $i$-umlaut associated most strongly with Wilhelm Scherer (1868, $144 \mathrm{f}$.).

As Stefan Sonderegger $(1979,302-04)$ explains, spellings of this kind have been traditionally taken as evidence that $i$-umlaut developed in Old High German through palatalisation of root vowels rather than vowel harmony: "The oldest umlaut graphemes of Old High German show not infrequently digraphic spellings ae, ei, ai for the $i$-umlaut reflex of a. In this we see an indication of an earlier, intermediate stage $\mathrm{a}^{\mathrm{i}}, \mathrm{a}^{\mathrm{e}}>\mathrm{e}^{\mathrm{i}}, \mathrm{e}^{\mathrm{e}}>\mathrm{e}^{\text {" }}$ (trans. Krygier 1998, 151). Jacob Grimm $(1840,104)$ and Wilhelm Scherer $(1868,144)$ were first to point out that the earliest Old High German indications of $i$-umlaut include digraphic spellings such as St Gallen

Mees, Bernard. "Egill and Qlrún in Early High German."

Futhark: International fournal of Runic Studies 8 (2017, publ. 2019): 151-156.

DOI: $10.33063 /$ diva-384658

(ㄷ) 2019 Bernard Mees (CC BY) 
aigi for later $e g \bar{i}$ 'disciplina' and the Tegernsee gloss ailliu for later alliu, elliu 'totus, omnis' (Seebold 2001, 110; 2008, 129). Scherer's palatalisation theory has largely been rejected in more recent scholarship in favour of W. Freeman Twaddell's (1938) vowel harmony model (Krygier 1998, Schulze 2010, Van der Hoek 2010). Yet given the orthographic evidence preserved in the early Old High German glosses, the palatal epenthesis seen in the Pforzen inscription is precisely what we would expect to find in such an early text. The spelling aill-, however, presumably shows that the underlying form in German was *ali- rather than the *alu- suggested by Old Norse $Q l-$.

Other etymologies for these forms have been developed. Norbert Wagner (1999), for example, disassociates aigil etymologically from Agila- and Egil(-), tracing it to an agentive derivative in -il of the preterite-present verb *aigana 'to own'. But as the spelling Ayglolfinga in Fredegar's chronicle (bk. 4, sec. 51) for the name of the Bavarian ducal Agilolfing dynasty suggests, the alternations of Egil- and Eigil- first noted by Ernst Förstemann (1900, 27-36) in early German sources can be explained without recourse to a nomen agentis of *aigana recorded only in German onomastics. Similar obscurum per obscurius attempts to explain the spelling ail- have proven even less convincing, the only plausible comparator offered being an etymologically isolated Old English lexeme āl 'fire' not (otherwise) reflected in German or onomastically (Findell 2012, 78). Descartes begins his Principia Philosophiae (1644; Principles of Philosophy [1983]) with the contention "The seeker after truth must once in his lifetime doubt everything that he can doubt", but there is little linguistic cause to dispute the notion that the names recorded as aigil and aillun in the Pforzen inscription reflect early German variants of Egill and Qlrún.

So what would the names of a heroic couple be doing on a Merovingian belt buckle? Given no suitable early runic comparators, the first place to look for parallels would be other belt buckle inscriptions found in Merovingian contexts. As Lisbeth Imer $(2015,110)$ remarks, "the best analogies for the inscriptions ought to be contemporary and found in roughly the same geographical area”, and inscribed buckles are well known from contemporary Burgundian sites. The Pforzen buckle is an example of the Alemannic Weingarten type, the only known buckle of this morphological genre that is inscribed (Windler 1989, Babucke 1999). Inscribed strap-ends are well known from Alemannic graves, with some even featuring Christian texts such as deus in adiutorium meum intende ' $\mathrm{O}$ God, come to my assistance' (Psalm 69:2 [Vulgate]) and ]elis suis mandauit de te ut costotiam te $i$ omibos $u i$ 'For he hath given his angels charge over 
thee; to keep thee in all thy ways' (Psalm 90:11 [Vulgate]; Düwel 1994, 255 f.). Over a dozen similarly dating buckles of Burgundian make, however, feature pictorial representations of the Biblical story of Daniel and the lions (Daniel 14), and often include descriptive inscriptions such as $+u u i$ Dagninil duo leones eed euus lengebant + Daidius '(long) may you live, Daniel two lions lick [his feet?], Daidius' and Daniel profeta, Abbacu profeta 'Daniel the prophet, Habakkuk the prophet'. Many more contemporary Burgundian buckles still are inscribed with explicitly amuletic expressions, featuring texts including Nasualdus Nansa + vivat deo utere felix Daninil 'Naswaldus Nansa (long) may you live (in) God, use luckily, Daniel' and Deenatus deaconus vivat ... deo im pace annus cen 'Renatus the deacon may you live in God, in peace for a hundred years' (Tischler 1982, Treffort 2002, Speidel 2011).

Buckles of this Burgundian amuletic type also sometimes feature small compartments used to carry relics. One of these is the Monnet-la-Ville buckle which bears the inscription Tonancius viva Maxo me fecit opdime fecio facio 'May you live (long) Donantius, Maxo made me best, I made, I make' (Werner 1979, Young 2009). Sometimes the Burgundian buckle plates even feature commissioner's texts such as Willimeres fece fibal Poemo cer 'Willemer made this buckle for the cleric Polemicus' or even a mixture like + Landelinus ficit numen, qui illa possiderauit viva usqui annus mili in do 'Landelinius made (a) divine (image), may he who shall possess it live for a thousand years in God' (Tischler 1982, Gaillard de Sémainville 2003). It seems quite clear that the Pforzen buckle belongs to a contemporary and geographically local genre of inscribed Merovingian amulets, albeit with apparent reference to a heroic pair, Aigil and Ailrun, where Burgundian buckles typically feature wishes for long life, depict the story of Daniel and the lions, or preserve less semiotically clear Christian pictorial expressions such as representations of griffins or saints. Given this context, Mindy MacLeod and Bernard Mees (2006, 19 f.) duly argue that the Pforzen text represents an example of a widely attested genre of magico-religious expression, the inscription's alliteration and verbfinal word order suggesting that it preserves some kind of historiola or narrative charm.

There remain key difficulties in interpreting the inscription on the Pforzen buckle. The orthographically unexpected form Itahu that opens the second line has been interpreted in several different (equally problematic) ways. Klaus Düwel's $(1999,47)$ connection of the form with Old High German elaho 'elk' seems more regular linguistically than Nedoma's (2004a, 354) invocation of an otherwise unattested hydronym and the association 
of the form with ideographs by Elmar Seebold $(2001,14)$ is unparalleled (cf. Seebold's equally unconventional proposal that the sequence usually read as aillrun begins with an "untypische Bindrune" $\widehat{\text { aq }}$ ). The alliteration suggests that a form cognate to Aldako (which seems to reflect an Old Saxon counterpart of Old High German altihho 'elder, veteran'-albeit with different apophony in the suffix) may have been intended (Crecelius 1864, 14). But Itahu is uncontroversially taken as representing the direct object of the verb gasōkun. The final term gasōkun is obviously a perfective development of Indo-European ' ${ }^{2} h_{2} g$ - 'seek' that is reflected in Gothic as gasakan 'to reprove, to reproach' and Old High German gisahhan 'to condemn', gisahha 'blame'. The Proto-Germanic verb *sakana is also reconstructed with a meaning 'to contend, to fight' by Don Ringe and Ann Taylor $(2014,232)$, but as 'to charge' by Guus Kroonen (2013, 423). Ottar Grønvik (2003) argued for the etymological primacy of the military meaning (presumably as a semantic development of 'seek (out in battle)' > 'approach' > 'fight' > 'reproach, blame' has occurred) and comparative evidence such as the Old Irish verb saigid 'to seek out, to approach, to attack' supports his presumption that the Old English strong verb sacan 'to fight, to contend; to sue, to blame, to accuse' is semantically more conservative than the recorded Gothic or Old High German perfective forms. But what precisely was intended by the second line of the early German buckle's text remains disputable. Only the opening line's alliterating names Aigil andi Ailrūn, the anastrophic, verb-last position of the verb gasōkun, and the appearance of amuletic inscriptions on comparable Burgundian belt buckles are absolutely clear considerations. Beck is surely right that too much has been made of the Pforzen buckle text in the past, but taken together its most clearly established features point most obviously to a magico-religious interpretation of the difficult Merovingian German find.

\section{Bibliography}

Babucke, Volker. 1999. "Die Runenschnalle von Pforzen (Allgäu)-Aspekte der Deutung. 1. Zur Herkunft und Datierung." In Bammesberger 1999, 15-24.

Bammesberger, Alfred, ed. 1999. Pforzen und Bergakker: Neue Untersuchungen zu Runeninschriften. Historische Sprachforschung, Ergänzungsheft 41. Göttingen.

Beck, Wolfgang. 2017. "Die Runeninschrift auf der Gürtelschnalle von Pforzen als Zeugnis der germanischen Heldensage?” Futhark 7 (2016): 29-45.

Crecelius, Wilhelm. 1864. Collectae ad augendam nominum propriorum Saxonicorum et Frisiorum scientiam spectantes. Vol. 1, Index bonorum et redituum monasteriorum Werdinensis et Helmonstadensis. Elberfeld. 
Descartes, René. 1644. Principia Philosophiae. Amsterdam. English translation: René Descartes. Principles of Philosophy. Trans. Valentine Rodger Miller and Reese P. Miller. Dordrecht, 1983.

Düwel, Klaus. 1994. "Runische und lateinische Epigraphik im süddeutschen Raum zur Merowingerzeit.” In Runische Schriftkultur in kontinental-skandinavischer und -angelsächsischer Wechselbeziehung: Internationales Symposium in der Werner-Reimers-Stiftung vom 24.-27. Juni 1992 in Bad Homburg, ed. Klaus Düwel, 229-308. ERGA, 10. Berlin.

—. 1999. "Die Runeninschrift auf dem Elfenbeinring von Pforzen (Allgäu) Aspekte der Deutung: Lesung und Deutung.” In Bammesberger 1999, 36-54.

ERGA = Ergänzungsbände zum Reallexikon der Germanischen Altertumskunde.

Findell, Martin. 2012. Phonological Evidence from the Continental Runic Inscriptions. ERGA, 79. Berlin.

Försteman, Ernst. 1900. Altdeutsches Namenbuch. Vol 1, Personennamen. 2nd ed. Bonn.

Gaillard de Sémainville, Henri. 2003. "Nouvel examen de la plaque-boucle mérovingiene de Landelinus découverte à Ladoix-Serrigny (Côte d'Or).” Revue archéologique de l'Est 52: 297-328.

Grimm, Jacob. 1840. Deutsche Grammatik. 3rd ed. Göttingen.

Grønvik, Ottar. 2003. “Die Runeninschrift von Pforzen.” In Runica-GermanicaMediaevalia, ed. Wilhelm Heizmann and Astrid van Nahl, 174-85. ERGA, 37. Berlin.

Imer, Lisbeth M. 2015. "The Inscriptions from Thorsberg - Germanic Inscription Making as a Reflection of Roman Writing." In Archäologie und Runen: Fallstudien zu Inschriften im älteren Futhark, ed. Oliver Grimm and Alexandra Pesch, 10916. Schriften des archäologischen Landesmuseums, Ergänzungsreihe, 13. Neumünster.

Kroonen, Guus. 2013. Etymological Dictionary of Proto-Germanic. Leiden IndoEuropean Etymological Dictionary Series, 11. Leiden.

Krygier, Marcin. 1998. "Epenthesis and Mouillierung in the Explanation of $i$-Umlaut: The Rise and Fall of a Theory.” In Advances in English Historical Linguistics, ed. Jacek Fisiak and Marcin Krygier, 151-59. Trends in Linguistics: Studies and Monographs, 112. Berlin.

MacLeod, Mindy, and Bernard Mees. 2006. Runic Amulets and Magic Objects. Woodbridge.

Marold, Edith. 1996. "Egill und Qlrún - ein vergessenes Paar der Heldendichtung." Skandinavistik 26: 1-19.

— . 2004. "Die Schnalle von Pforzen und die altnordische Heldensage." In Verschränkung der Kulturen: Der Sprach- und Literaturaustausch zwischen Skandinavien und den deutschsprachigen Ländern: Zum 65. Geburtstag von Hans-Peter Naumann, ed. Oskar Bandle, Jürg Glauser and Stefanie Würth, 217-38. Beiträge zur nordischen Philologie, 37. Tübingen. 
Nedoma, Robert. 1999. "Die Runeninschrift auf der Gürtelschnalle von Pforzenein Zeugnis der germanischen Heldensage.” In Bammesberger 1999, 98-109.

— . 2004a. "Noch einmal zur Runeninschrift auf der Gürtelschnalle von Pforzen." In Alemannien und der Norden: Internationales Symposium vom 18.-20. Oktober 2001 in Zürich, ed. Hans-Peter Naumann, 340-70. ERGA, 43. Berlin.

—. 2004b. Personennamen in südgermanischen Runeninschriften: Studien zur altgermanischen Namenkunde I, 1, 1. Indogermanische Bibliothek, 3rd ser.: Untersuchungen. Heidelberg.

Ringe, Don, and Ann Taylor. 2014. The Development of Old English. A Linguistic History of English, 2. Oxford.

Scherer, Wilhem. 1868. Zur Geschichte der deutschen Sprache. Berlin.

Schulze, Jan Henning. 2010. Der i-Umlaut im Althochdeutschen: Theorie, Phonetik und Typologie sowie eine optimalitätstheoretische Analyse. Bamberger Beiträge zur Linguistik, 3. Bamberg.

Seebold, Elmar. 2001. Chronologisches Wörterbuch des deutschen Wortschatzes. [Vol. 1,] Der Wortschatz des 8. Fahrhunderts (und früherer Quellen). Berlin.

— . 2008. Chronologisches Wörterbuch des deutschen Wortschatzes. Vol. 2, Der Wortschatz des 9. Jahrhunderts. Berlin.

Sonderegger, Stefan. 1979. Grundzüge deutscher Sprachgeschichte: Einführung, Genealogie, Konstanten. Berlin.

Speidel, Michael P. 2011. "Burgundian Gods on Sixth-Century Belt Buckles, Part 1: The Buckles from Saint-Maur and Saint-Quentin.” Frühmittelalterliche Studien 45: 1-36.

Tischler, Johann. 1982. "Die Aufschriften der burgundischen Danielschnallen." Beiträge zur Namenforschung, n.s., 17: 113-60.

Treffort, Cécile. 2002. "Vertus prophylactiques et sens eschatologique d'un depot funéraire du haut Moyen Age: Les plaques boucles rectangulaires burgondes à inscription." Archéologie médiévale 32: 31-53.

Twaddell, W. Freeman. 1938. "A Note on Old High German Umlaut.” Monatshefte für Deutschen Unterricht 30: 177-81.

Van der Hoek, Michel. 2010. "Palatalisation in West Germanic." Ph.D. dissertation, University of Minnesota.

Wagner, Norbert. 1999. “Ahd. Eigil(-).” In Bammesberger 1999, 114-17.

Werner, Joachim. 1979. "Die romanische Trachtprovinz Nordburgund im 6. und 7. Jahrhundert." In Von der Spätantike zum frühen Mittelalter: Aktuelle Probleme in historischer und archäologischer Sicht, ed. Joachim Werner and Eugen Ewig, 447-65. Vorträge und Forschungen, 25. Sigmaringen.

Windler, Renata. 1989. "Ein frühmittelalterliches Männergrab aus Elgg (ZH): Bemerkungen zu einem filigranverzierten Schnallentyp.” Jahrbuch der Schweizerischen Gesellschaft für Ur- und Frühgeschichte 72: 181-200.

Young, Bailey K. 2009. "The Imagery of Personal Objects: Hints of 'Do-It-Yourself' Christianity in Merovingian Gaul?" In The Power of Religion in Late Antiquity, ed. Andrew Cain and Noel Lenski, 339-54. Society for Late Antiquity, 5. Farnham. 